\title{
BAWINE: KARYA TARI YANG TERISNPIRASI PADA CITRA PEREMPUAN BUTON
}

\author{
Waode Muriani Ekasari Virno Bolu \\ Program Seni Tari, Fakultas Seni dan Desain \\ Universitas Negeri Makassar \\ Email: waodenhini@gmail.com
}

\begin{abstract}
RINGKASAN
Bawine dalam bahasa Buton berarti perempuan. Karya tari ini terinspirasi dari sosok perempuan Buton yang ditulis dalam buku Perempuan dalam Khabanti yang sangat ingin melakukan segala sesuatu sesuai dengan keinginannya tetapi dibatasi oleh aturan tradisi yang tidak membolehkan wanita bekerja, bersekolah, dan menentukan jodohnya sendiri. Karya ini juga dikaitkan dengan keadaan perempuan Buton saat ini yang bebas menentukan jalan hidup dan memilih hak untuk melanjutkan pendidikan ke jenjang yang lebih tinggi. Tari Bawine ditarikan oleh tiga penari wanita yang masing-masing memiliki peran masing-masing. Penari pertama menggambarkan perempuan yang masih terkungkung, penari kedua menggambarkan wanita tradisi yang menjadi pisau bedah untuk ke luar dari aturannya, dan penari ketiga menggambarkan perempuan dari generasi sekarang yang bebas menentukan pilihannya.
\end{abstract}

Kata Kunci: Bawine, perempuan, Buton

\section{ABSTRACT}

Bawine is a Buton language which means female. This dance work is inspired by the female figure of Buton written in the book Perempuan in Khabanti, who is keen to do everything with his desire but is limited by traditional rules that do not allow women to work, go to school, and determine their own soul mates. This work is also associated with today's women who are free to determine the way of life and choose the right to continue their education at a higherlevel. Bawine dance is danced by three female dancers who each have their roles / characters. 1) dancers who describe their constraints, 2) dancers who describe traditional women who become scalpels to get out of their rules, and 3) dancers who describe women who have been associated with the present who are free to make their choices.

\section{Keywords: Bawine, woman, Buton}




\section{PENDAHULUAN}

Bawine dalam bahasa Buton berarti perempuan. Karya tari ini akan mengangkat citra perempuan Buton yang digambarkan di dalam teks Khabanti --(lagu daerah bahasa Wolio)-- yaitu salah satu bentuk tradisi lisan tertua dalam masyarakat Buton. Perempuan Buton selama ini dicitrakan sebagai makhluk yang tidak berdaya. Dari hasil pembacaan teks Khabanti, maka diciptakan karya tentang citra perempuan Buton untuk mendorong terjadinya proses kesadaran pada perempuan berdasarkan potensi yang dimilikinya. Beberapa teks Khabanti yang menggambarkan perempuan dulu yang terkekang dengan aturan yaitu:

1. E wa ina na runga-runga-su E te susa ku-dumpali-ne-mo

Ibu, betapa aku masih muda Tapi susah aku telah jumpai

2. E wa ina ane ngko-mohoha'a?

E ra ku-mala ntelaro-su

Ibu, apa yang bisa kamu perbuat? Kalau saya mengikuti kata hatiku

3. E wa inata-mogagai-mo

E ta-miti-mo sampoliu'a

Ibu, kita akan berselisih

Kita akan berbeda pilihan

Teks Khabanti di atas, menggambarkan dialog antara perempuan sebagai anak dan peran perempuan sebagai ibu rumah tangga. Dialog tersebut terlihat bahwa si aku "lirik perempuan sebagai anak" memiliki keterbatasan dalam menentukan pilihannya. Peran perempuan sebagai orang tua di dalam teks Khabanti memperlihatkan adanya perubahan peran orang tua dalam keluarga tradisional yang membelenggu anak-anaknya menjadi keluarga modern yang demokratis.

Di dalam teks Khabanti perempuan Buton memiliki 3 peran dalam kehidupan keluarga dan sosial, yaitu (1) sebagai ibu, (2) sebagai anak, dan (3) dan sebagai tuan rumah. Dari peran-peran tersebut, peran perempuan sebagai ibu mempunyai potensi yang dapat membentuk mental dan karakter pada anak. Oleh karena itu, perempuan di Buton sangat dibatasi ruang lingkupnya agar dapat menjaga dirinya dari dunia luar yang telah terkontraminasi.

Gadamer menjelaskan bahwa kita tidak dapat memahami sejarah dengan cara berdiri di atas sejarah atau dengan sikap mengobyektivitasi karena kita adalah makhluk historis. ${ }^{1}$ Sebagai penafsir terhadap historis perempuan yang ditulis dalam Khabanti, penulis merepresentasi citra perempuan Buton yang berhubungan dengan aspek sosial adalah sikap interaksi perempuan dalam keluarga dan masyarakat

1 F. Budi Hardiman. 2015. Seni MemahamiHermeneutik dari Schleirmacher sampai Derida, Yogyakarta: Kanisius, p.54 
JOGED

ISSN: $1858-3989$

yang masih terbatas. Oleh karena itu, perempuan yang digambarkan dalam citra perempuan Buton adalah perempuan yang ingin lepas dari ikatan untuk mampu berdemokrasi, membangun dialog dan perlawanan terhadap adat dan budayanya dengan menunjukkan bahwa representasi tersebut merupakan jalan ke luar perempuan yang selama ini terbelenggu dalam kehidupan sosial mereka. Rasa kritis perempuan tersebut merupakan potensi yang dimiliki perempuan Buton untuk melakukan dialog terus-menerus guna mewujudkan kehidupan masyarakat yang lebih demokratis dan terbuka. Penulis menginterprestasikan bahwa budaya masyarakat tersebut harus dikritisi untuk mencari nilai-nilai budaya yang memberi kesempatan kepada perempuan untuk bersosialisasi dengan kehidupannya.

Terinspirasi dari peran perempuan dalam teks Khabanti dan disangkutpautkan dengan sosok ibu dalam cerita rakyat Wandiu ndiu yang mendorong untuk mewujudkan karya tari tentang citra perempuan dalam masyarakat Buton.

Buton dipahami sebagai sebuah wilayah geografis dan budaya. Ada beberapa sumber sejarah maupun legenda yang dipercaya merupakan cikal bakal budaya dan masyarakat Buton. Kisah yang pertama meyakini cikal bakal Buton sebagai negeri
Waode Muriani Ekasari Virno Bolu I BAWINE: KARYA TARI YANG TERISNPIRASI PADA CITRA PEREMPUAN BUTON

telah dirintis oleh empat orang yang disebut dengan Mia Patamiana. Mereka adalah: Sipanjonga, Simalui, Sitamanajo, Sijawangkati. Menurut sumber sejarah lisan, empat orang pendiri negeri ini berasal dari Semenanjung Melayu yang datang ke Buton pada akhir abad ke-13 M. Mereka mulai membangun perkampungan yang dinamakan Wolio yang saat ini terletak di kota Baubau, Sulawesi Tenggara.

Kisah yang kedua merupakan legenda Tula-Tulana Wandiu ndiu yang menjadi cerita turun temurun masyarakat di suku Buton yang penyampaiannya dilakukan secara lisan. Tula-tulana wandiundiu atau dalam bahasa Indonesia berarti "cerita asal mula ikan duyung". Diceritakan, dahulu kala di pulau Buton hiduplah satu keluarga kecil yang terdiri dari kepala keluarga, ibu rumah tangga, anak sulung bernama Laturunkoleo dan anak bungsu bernama Lambata-mbata. Pekerjaan sang suami adalah seorang nelayan, sedangkan sang istri bertugas mengurus rumah tangga dan mendidik kedua anaknya.

Sebelum memasuki musim Barat, seperti biasa sang ayah menyimpan persediaan hasil tangkapannya di rumah. Pada musim Barat, nelayan berganti profesi dengan bercocok tanam, karena pada saat itu angin bertiup dengan kencang, menyebakan 
gelombang yang besar, sehingga membahayakan bagi nelayan. Sebelum bergegas pergi ke kebun sang ayah berpesan kepada istrinya agar ikan yang masih tersisa jangan dimakan oleh siapapun sebelum ia pulang ke rumah. Istrinya pun menyanggupi permintaan sang suami. Namun untung tak dapat diraih, malang tak dapat ditolak, tak berapa lama kemudian sang anak bungsu Lambata-mbata terbangun dari tidurnya karena lapar. Ibunya kemudian pergi ke dapur untuk mencari makan, tetapi tak ada makanan apapun yang tersisa kecuali ikan yang sengaja disimpan oleh sang ayah. Karena tidak tega melihat Lambata-mbata yang terus menangis karena kelaparan, akhirnya sang ibu mengambilkan ikan milik ayahnya dan diberikan kepada Lambatambata.

Saat sang ayah tiba di rumah dengan letih dan lapar, ia langsung melangkahkan kakinya ke dapur untuk mencari ikan yang telah ia simpan. Melihat ikan yang ia simpan telah dimakan, membuat sang ayah murka dan memukuli serta menendang istri dan anaknya. Sang ibu yang sangat menyesali perbuatannya hanya menangis pilu. Kemudian ia berjalan ke arah pantai untuk mencari ikan pengganti yang dimakan oleh anaknya. Kedua anaknya mencoba untuk menahannya namun sang ibu mengatakan bahwa ia tidak akan naik ke darat sebelum ia menemukan ikan yang telah dimakan anaknya. Laturunkoleo yang tidak tega melihat adiknya yang terus menangis karena mencari sang ibu, akhirnya membawa adiknya ke pesisir pantai dan memanggil-manggil ibunya dengan nyanyian Khabanti (lagu daerah bahasa Wolio). Akhirnya munculah keajaiban dari yang Kuasa, ibu mereka datang dan menghampiri sembari memberikan ikan sesuai janjinya kepada Laturunkole, namun tak berapa lama kemudian separuh badan ibu mereka mulai bersisik seperti seekor ikan.

Pada cerita rakyat Wandiu ndiu ini banyak poin yang dapat dipetik, salah satunya bagaimana perempuan Buton dapat menjadi pondasi utama dalam sebuah keluarga, sehingga ruang lingkupnya dibatasi dengan aturan dan adat. Jika disangkutpautkan dengan keadaan saat ini, keterbatasan dapat menjadi poin yang diambil, karena kebebasan mengikuti modernisasi yang sudah sangat jauh melaju dapat mengakibatkan hal negatif pula pada citra perempuan. Keputusan "peran ibu" dalam cerita rakyat Wandiu ndiu bisa diambil dari segi pengorbanannya yang rela meninggalkan keluarga agar ia bisa menggantikan apa yang diinginkan oleh anaknya. Cerita rakyat ini juga menjadi salah satu pola kehidupan di masyarakat 
Buton, di mana kekeluargaan sangat penting hingga apapun yang terjadi mereka akan membentengi keluarganya.

Pada karya ini diharapkan tercapainya nilai-nilai yang terkandung dalam cerita Wandiu ndiu yaitu bagaimana seorang wanita dapat mengeluarkan pendapatnya, seorang wanita yang tidak hanya diam jika mendapatkan kekerasan dalam rumah tangga, serta mengekspresikan kesedihannya yang harus berpisah dari keluarganya ketika seorang wanita telah ke luar dari rumah. Penata menciptakan sebuah karya tari yang di dalamnya terdapat beberapa komponen yang saling berkaitan antara kodrat wanita Buton yang ingin menentukan jalan hidupnya, ingin menyuarakan pendapatnya, serta dikaitkan dengan dunia perempuan yang saat ini telah bisa bebas untuk melihat dunia. Dalam karya ini akan dimunculkan berbagai ekspresi yang saling berkaitan dalam berkreativitas.

Karya Bawine akan ditampilkan dengan penataan panggung yang menggambarkan suasana terkekang hingga berubah ke suasana yang bebas dan bisa membuka diri. Penari pada karya ini berjumlah 3 orang dengan peran masing-masing sesuai dengan karakter tokoh di dalam cerita.

\section{PEMBAHASAN}

\section{A. Metode Penciptaan}

Setiap penggarapan karya seni, tentu akan mengalami proses penggarapan yang berbeda. Dalam penggarapan karya tari diperlukan kemampuan yang didukung oleh daya kreativitas. Menurut Y. Sumandiyo Hadi, dalam bukunya Mencipta Lewat Tari hasil terjemahan dari buku Creating Thourgh Dance oleh Alma M. Hawkins, terdapat tiga tahap dalam proses penggarapan sebuah karya seni, yaitu tahap eksplorasi, tahap improvisasi, dan tahap pembentukan. Dalam pelaksanaannya pada ketiga tahap tersebut antara satu dengan yang lainnya sangat terkait. Berdasarkan uraian di atas, maka penggarapan tari ini telah melalui proses yang cukup panjang dengan berpijak pada urutan tahapan di atas.

\section{Tahap Eksplorasi}

Eksplorasi merupakan proses awal dari segala bentuk kegiatan dari kreativitas yang dilakukan dalam suatu karya tari. Berpikir, berimajinasi, melakukan pencarian ide, serta menafsirkan sebuah tema, yang kemudian diperkuat dengan mengumpulkan berbagai sumber bacaan baik berupa buku, makalah, dan sumber bacaan lainnya. Tahapan ini diawali dengan pengumpulan sumbersumber berupa literatur atau buku-buku 
penunjang tema yang akan digarap dan tema yang akan diangkat, dan juga menentukan para pendukungnya apakah akan digarap dalam bentuk kelompok, duet, atau tunggal, serta mulai berpikir tentang penari, penata lampu, penata artistik maupun penata musiknya. Dalam tahap ini proses eksplorasi dilanjutkan dengan eksplorasi tubuh, mencari kemungkinan-kemungkinan berbagai motif gerak yang sesuai dengan garapan ini, sehingga diharapkan mampu menciptakan struktur gerak tari yang sesuai dengan tema yang akan disajikan dengan memiliki nilai inovasi (kebaruan). Tahap ini diawali dengan pencarian ide atau gagasan maupun konsep yang digunakan, baik dari membaca ataupun menonton seni pertunjukan. Penata berkeinginan untuk menggarap karya dengan biaya produksi sedikit namun tetap memenuhi standar.

Pada tahap eksplorasi ini dilakukan berdiskusi dengan teman-teman agar bisa memberikan masukan, mencari informasi dan data-data, kemudian mencari motif dan kemungkinan-kemungkinan gerak yang sesuai dengan perilaku perempuan Buton.

\section{Tahap Improvisasi}

Pada tahap ini dipikirkan motif-motif gerak yang akan digunakan dalam garapan. Tahap ini dilakukan dengan mengulang bagian per bagian dalam waktu yang tidak ditentukan, karena kemungkinankemungkinan perkembangan gerak muncul sehingga terjadi perubahan motif dan frase gerak yang sudah ada. Proses improvisasi pencarian gerak ini dilakukan dengan bergerak bebas menuruti gerakan hati sampai ditemukan gerak yang tepat untuk kemudian dipilih gerak-gerak yang cocok dan sesuai dengan tema dari garapan ini. Tahap improvisasi ini, gerak dicoba terusmenerus, sehingga bagian per bagian dapat tersusun, walaupun secara global saja tanpa adanya penonjolan ekspresi. Dari hasil improviasasi, gerak-gerak yang telah terseleksi dan telah dianggap sesuai berulah disusun ke dalam frase gerak.

Tahap ini dilakukan sendiri di studio, membuat bagian per bagian, kemudian gerak-gerak yang telah ditemukan di tahap eksplorasi diulang beberapa kali, baru kemudian dibentuk dan disesuaikan dengan kebutuhan. Pada tahap ini, dimintakan juga saran dari orang lain yang melihat proses ini. Biasanya dimintakan masukan mengenai sampai tidaknya makna yang diinginkan pada saat berdiskusi dengan teman-teman.

\section{Tahap Pembentukan}

Pada tahap ini dilakukan pemilihan gerak-gerak yang sesuai dengan ide garapan. Pemilihan gerak juga didasarkan pada ide dasar yang meliputi tema, cerita, 
JOGED

ISSN: 1858-3989

watak, dan gerak-gerak yang menjadi ciri dari ide dasarnya. Susunan gerak tersebut meliputi gerak kaki, gerak tangan, gerak kepala, dan gerak tubuh atau torso. Pada tahap ini juga dilakukan perancangan struktur ataupun alur sehingga menjadi suatu pola gerakan. Hasil dari suatu pola di atas disebut koreografi. Kemudian diperagakan secara berulang-ulang.

Tahap pembentukan ini dilakukan bersama dengan penari. Pada pertemuan awal, penata menceritakan tema dan menentukan tokoh pada penari. Kemudian menyusun adegan per adegan, dan menentukan gerak yang telah didapatkan pada eksplorasi dan improvisasi.

\section{B. Proses Berkarya}

Kreativitas merupakan proses pencarian ke dalam diri sendiri yang penuh tumpukan kenangan, pikiran, dan sensasi sampai ke sifat yang paling mendasar bagi kehidupan. Beberapa pengalaman indra telah menghasilkan rangsangan atau motivasi yang memerlukan tindakan kreatif (Hawkins, 1988:23). Pada karya tari ini penata mendapatkan rangsang awal dari buku mengenai Perempuan dalam Khabanti.
Waode Muriani Ekasari Virno Bolu I BAWINE: KARYA TARI YANG TERISNPIRASI PADA CITRA PEREMPUAN BUTON

1. Rangsang Awal

Munculnya sebuah ide dalam menciptakan karya seni berawal dari adanya rangsang. Rangsang inilah yang membuat lahirnya sebuah karya seni. Rangsang didefinisikan sebagai suatu yang membangkitkan pikir dan mendorong kegiatan. Rangsang membentuk denyut dasar di belakang dan selanjutnya membentuk sebuah sturktur. Rangsang gagasan (ideasional) merupakan gerak yang dirangsang dan dibentuk dengan intensi untuk menyampaikan gagasan atau menggelar cerita. (Louis Elfeltd, 1977:14).

Citra perempuan Buton dalam Khabanti memberikan sebuah ide kepada penata untuk menciptakan karya Bawine. Fokus pada eksplorasi dan menginterprestasikan citra perempuan Buton yang menyimbolkan keterbatasan dan keterkungkungan pada perempuan pada zaman dulu dan mengaitkannya dengan zaman sekarang yang akhirnya memunculkan masalah pemberontakan dan ingin terlepas dari suatu keterbatasan. Adapun 3 karakter yang dimunculkan pada karya ini adalah, karakter perempuan tradisi yang terbatas ruang lingkupnya, karakter perempuan yang terkungkung pada aturan dan tidak bisa menyuarakan pendapatnya, dan karakter perempuan modern yang menjadi pisau 
pembedah terhadap terjadinya permasalahan.

\section{Tema Tari}

Tema tari merupakan hal yang penting dan mendasar dalam sebuah karya tari. Dalam karya tari ini menggunkan tema yang lahir dari kehidupan sosial penata yang bertempat tinggal di Buton dan juga banyak membaca mengenai sejarah wanita Buton pada zaman dahulu. Tema dalam karya tari ini adalah "Perempuan". Tema perempuan ini akan mengarah dan membantu dalam proses penggarapan sebagai patokan sampai tidaknya pesan yang akan disampaikan.

Perempuan yang diangkat pada karya ini yaitu perempuan Buton yang menjadi titik fokus penata dalam karya Bawine. Citra diri perempuan yang digambarkan di dalam teks-teks Khabanti masih berada dalam ketegangan, keinginan untuk maju dan kungkungan budaya yang membelenggu. Terdapat dinamisasi psikis, yaitu ada yang mampu menentukan nasibnya sendiri namun ada juga yang tidak. Sedangkan citra perempuan dalam keluarga dan masyarakat yang digambarkan dalam teks-teks Khabanti adalah perempuan sebagai ibu rumah tangga, perempuan sebagai anak, dan perempuan sebagai tuan rumah. Pencitraan mengenai peran perempuan di dalam masyarakat Buton, dapat dilihat dari hubungan-hubungan antar individu dengan individu, maupun antar individu dengan masyarakat. Bagaimana seorang perempuan yang zaman dahulu menghadapi kehidupannya yang memiliki ruang lingkup yang terbatas, dan bagaimana seorang perempuan berusaha untuk bisa ke luar dari keterkungkungan tersebut. Kebebasan dalam menentukan pilihan ini bisa dilihat dalam citra perempuan dalam Khabanti yang mempertanyakan nasibnya dan ingin melakukan perubahan. Sedangkan jika dilihat dari cerita rakyat Wandiu ndiu kebebasan dalam memilih terlihat pada peran si ibu dalam menentukan pilihannya dengan meninggalkan keluarganya.Tema perempuan ini akan mengarah sebagai patokan untuk membantu dalam proses penggarapan agar pesan yang diinginkan dapat tersampaikan.

\section{Judul Tari}

Judul dalam sebuah karya tari merupakan sebuah susunan kata untuk memperjelas kepada penonton. Pada umumnya judul sangat erat hubungannya dengan tema tari tersebut. Dalam pertunjukan memiliki esensi atas impressioni atau kesan terhadap pertunjukan. Penata mengangkat judul tari "Bawine" yang berarti perempuan. Judul 
tari ini diharapkan dapat mengantarkan pemikiran terhadap karya tari ini.

Judul "Bawine" dipilih karena esensi yang ingin diangkat dalam karya ini adalah perempuan. Bagaimana sikap perempuan Buton zaman dahulu yang sangat dibatasi ruang lingkupnya dan bagaimana sikap perempuan Buton saat ini yang sangat bebas. Sebutan Bawine adalah ketika seorang perempuan Buton telah melewati masa pingitan selama delapan hari delapan malam, dan telah siap menjalani kehidupan sesungguhnya sebagai seorang wanita yang akan menjadi ibu rumah tangga.

\section{Tipe Tari}

Jacqueline Smith membedakan tipe tari menjadi : (1) murni atau pure, (2) abstrak, (3) liris atau lyirical, (4) dramatik, (5) komik atau comic, (6) dramatari atau dance drama, (7) studi atau study. (Jacqueline Smith, 1985 : 24 - 28). Dalam hal ini tipe tari yang digunakan yaitu dramatik yang akan ditampilkan melalui gerak maupun ekspresi dari penari, sehingga gerak yang ada dalam karya tari ini dapat berfungsi sebagai perwujudan sosok perempuan sebagai titik fokus pada karya Bawine.

Tipe tari dramatik mengandung arti bahwa gagasan yang hendak dikomunikasikan sangat kuat dan penuh daya pikat (menarik), dinamis, dan banyak ketegangan. Dramatik mungkin lebih menekankan pada konflik batin antara perempuan Buton dengan kebebasan bersosialisasi.

Gerak yang tercipta merupakan hasil dari eksplorasi dan improvisasi dengan menggunakan gerak-gerak yang bisa mendukung dramaturgi karya Bawine. Gerak yang dipilih adalah gerak yang mampu mewakili maksud dan tujuan dari apa yang akan disuguhkan pada karya tersebut. Penekanan naik dan turunnya drmaturgi akan lebih memperjelas karya tari ini.

\section{Mode Penyajian}

Dalam sebuah karya tari, mode penyajian merupakan salah satu cara menyampaikan atau mengungkapkan maksud dan makna secara langsung dan tidak langsung. Mode penyajian tari secara simbolis dimaksudkan bahwa mode penyajian ini tidak menekankan pelukisan objek secara nyata karena kenyataan dianggap tidak mampu untuk menyampaikan isi tari. Yang ditampakkan dalam koreografi ini adalah esensi yang lebih menawarkan suatu kedalaman makna. Pada umumnya penampilan tari yang simbolis wujudnya adalah abstrak. Penyampaian pesan kepada penonton 
melalui gerak-gerak simbolis yang dicipta dan melalui aspek pendukung baik itu properti, kostum, dan setting saat pertunjukan. Kemudian gerak-gerak yang dihadirkan adalah motif gerak tari Buton dan tari Pakarena.

Skat adalah properti yang akan mengungkapkan karakter perempuan yang memiliki keterbatasan sesuai dengan citra perempuan dalam Khabanti yang masih berada dalam ketegangan, keinginan untuk maju dan kungkungan budaya yang membelanggu.

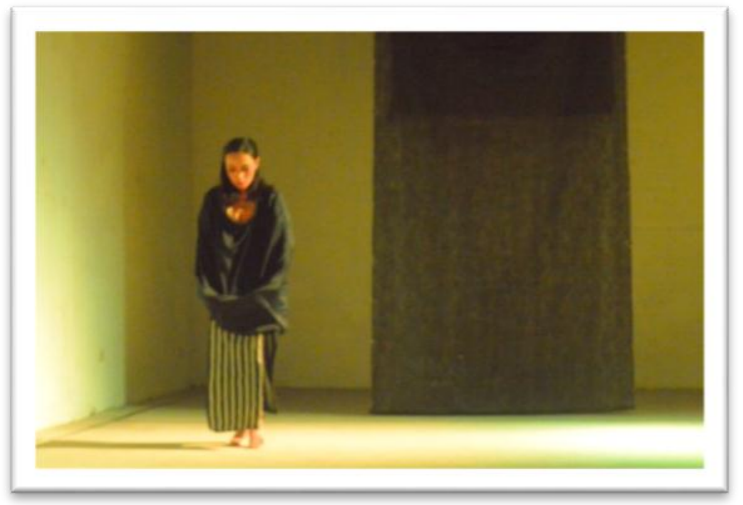

Gambar 1. Karakter penari 2 dengan skat yang mengikat tangannya (Foto: Haris, 2018)

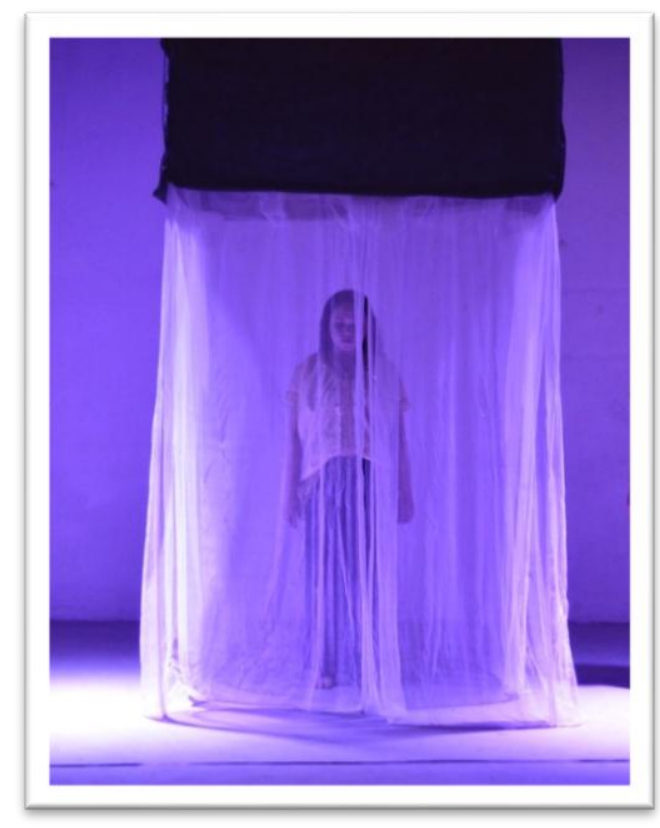

Gambar 2. Penari 1 dengan skat yang membatasi ruang lingkupnya (Foto: Haris, 2018)

\section{Gerak Tari}

Tari sebagai sebuah seni komunikatif menggunakan gerak sebagai materinya (Hawkins, terj Hadi, 2003: 3). Sumber Gerak tari yang digunakan dalam karya ini adalah sumber gerak interprestasi mengenai penokohan yang telah ditentukan oleh penata, yaitu eksplorasi dari pengamatan mengenai ketertekanan dan juga kebebasan. Gerak yang dipilih adalah gerak yang mampu mewakili maksud dan tujuan dari apa yang akan disuguhkan pada karya tersebut. Untuk menambah karakteristik kedaerahan sumber gerak yang dipakai adalah tari tradisional Sulawesi yakni tari Kalegoa, tari Pakarena, dan tari Lariangi. Esensi gerak tari Pakarena yang lambat, 
JOGED

ISSN: $1858-3989$

dikembangkan menjadi gerak yang dinamis disesuaikan dengan tempo cepat. Selain pengembangan gerak tradisi, gerak yang dihadirkan merupakan pengembangan gerak yang telah dieksplorasi dengan pemikiran mengenai citra perempuan dalam Khabanti.

Dalam karya tari ini tidak sebatas hanya mengacu pada bentuk gerak saja namun ada unsur yang lain berupa ekspresi atau mimik wajah yang memancarkan kesedihan dan kebingungan serta ketegangan. Ekspresi tersebut berguna untuk menyampaikan suasana hati yang sedang digambarkan melalui gerak tari. Sebuah kesulitan tersendiri bagi penata agar dapat menghayati rasa gerak serta menciptakan suasana hati yang berubah-ubah agar sesuai dengan suasana dalam gerak yang dimaksud.

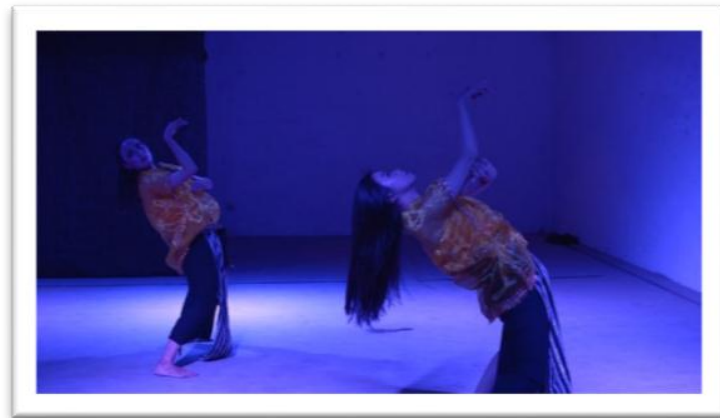

Gambar 3. Penari 2 yang mencoba mengikuti modernisasi setelah melepaskan skat yang membelenggu tangannya.

(Foto:Haris, 2018)
Waode Muriani Ekasari Virno Bolu I BAWINE: KARYA TARI YANG TERISNPIRASI PADA CITRA PEREMPUAN BUTON 
kesatuan, maupun gerak pecah juga dimunculkan melalui tiga penari tersebut.

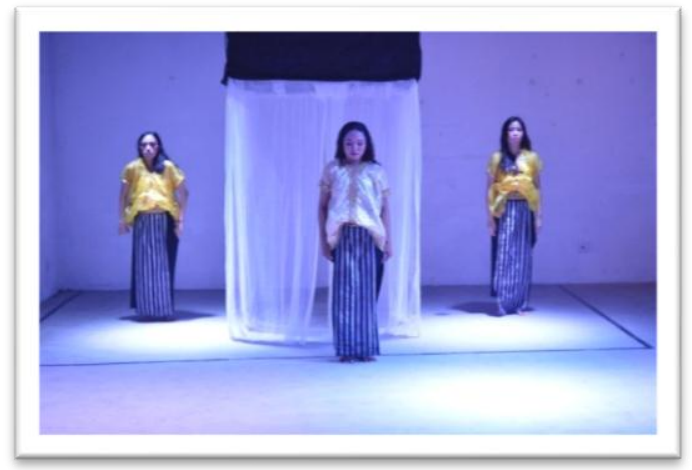

Gambar 5: Penari 1 keluar dari keterbatasan tradisi setelah mendapatkan pengaruh dari penari 2 dan3 (Foto: Haris, 2018)

\section{Musik Tari}

Dalam konsep garapan ini penata memilih musik MIDI (Musical Instrumen Digital Interfence) sebagai pengiring tari. Musik awal dibunyikan instrumen yang akan membawa suasana tertutupnya raga di dalam sebuah aturan, dan juga senandung yang dinyanyikan. Kemudian instrumen yang lebih komplit menggambarkan keresahan dalam segala aturan dan batasan yang dialami perempuan Buton.

Intro : Menggambarkan suasana perempuan tradisi yang terkungkung, awal musik menggunakan musik melodis yang menggambarkan suasana hati perempuan yang terkungkung dan ingin terlepas dari kungkungannya.

Adegan I : Musik yang lebih kompleks dengan tambahan perkusi menekankan penggambaran pemberontakan penari 2 agar lepas dari ikatan yang membelenggu ruang lingkupnya. Selanjutnya, ditambah dengan suara-suara bising dengan kata-kata yang komplit pada saat penari 3 masuk menggambarkan suasana yang bebas dari ikatan.

Adegan II : Pada suasana konflik, penata musik memasukan musik yang melodis yang menggambarkan pemberontakan hingga penari 2 melepaskan ikatannya, kemudian merasakan kebebasannya.

Adegan III : Musik yang digunakan adalah musik pianio dengan perkusi yang menggambarkan keresahan penari 1 apakah bebas yang diinginkan seperti ini? Dengan memunculkan kembali suara-suara bising dan bunyi sirine yang nyaring pada bagian ending.

\section{Tata Rias dan Busana}

Tata rias wajah yang digunakan adalah rias wajah korektif cantik dengan riasan mata yang tajam. Riasan tersebut bertujuan untuk menampilkan sosok perempuan yang Bawine sebagai perempuan yang memiliki ketegangan batin atas batasan-batasan yang dimilikinya. Busana dalam suatu garapan tari sangatlah berperan karena dari 
JOGED

ISSN: $1858-3989$

penampilan kostum, penonton tidak dapat menangkap gaya daerah tertentu. Sehubungan dengan itu maka busana yang digunakan masih berpijak pada konsep tradisi yaitu kombinasi baju daerah yang telah dimodifikasi sesuai kebutuhan penari.

Baju yang digunakan yaitu baju dengan kain transparan kuning dan kemben kuning di dalam baju, baju ini merupakan baju bodo yang telah dimodifikasi. Rok yang digunakan adalah rok span dengan aplikasi kain Buton di bagian depan, dengan aksen terbelah di bagian kiri rok. Belahan rok ini menjadi simbol perempuan yang ingin terlepas dari aturan, saat gerak membuka kaki, mereka bisa merasakan kebebasannya.

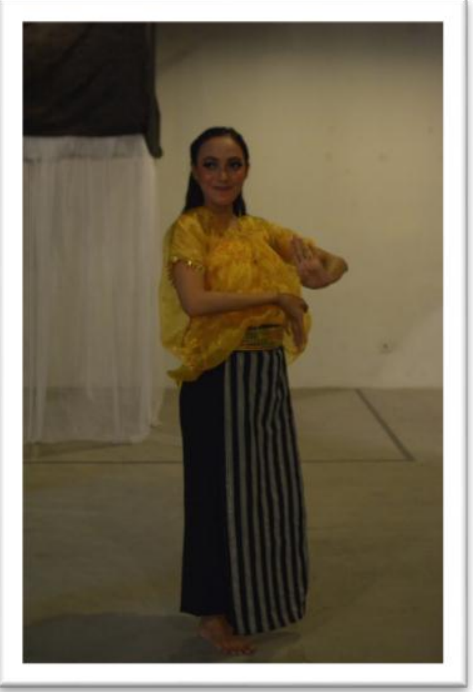

Gambar 6. Kostum yang digunakan penari. (Foto: Haris, 2018)

10. Properti Tari

Adapun masalah properti yang dipergunakan dalam garapan ini adalah kain dan skat. Penggunaan properti ini sengaja
Waode Muriani Ekasari Virno Bolu I BAWINE: KARYA TARI YANG TERISNPIRASI PADA CITRA PEREMPUAN BUTON

dipilih karena akan dipergunakan sebagai pelambang simbol perempuan yang terkungkung pada aturan adat tradisi. Properti ini digunakan pada bagian awal yang melambangkan situasi batasan-batasan tradisi

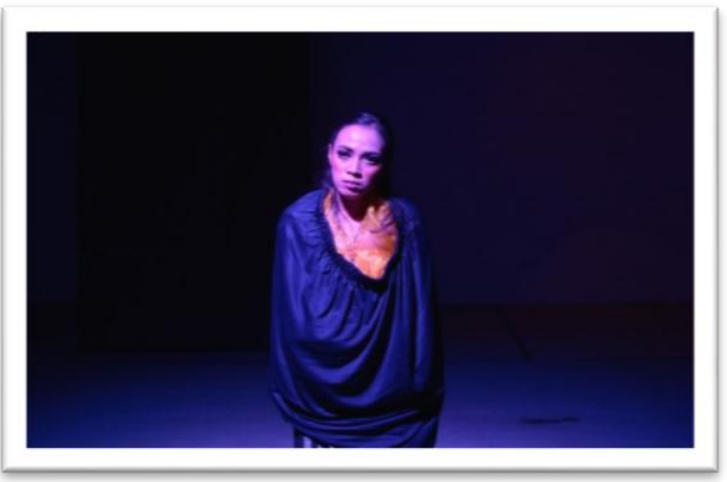

Gambar 7: Proporti Kain yang digunakan penari 2 (Foto : Haris, 2018)

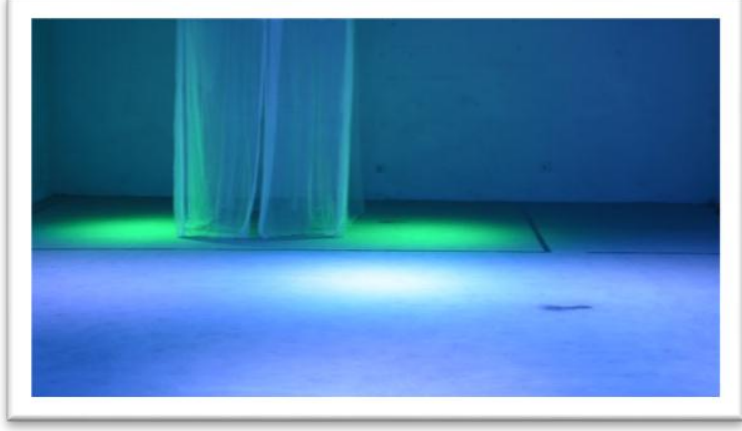

Gambar 8 : Properti Skat yang digunakan penari 1 (Foto : Haris, 2018)

11. Adegan

Karya tari ini terdiri dari empat adegan yaitu :

a. Introduksi

Satu orang penari perempuan berada di dalam skat dengan satu cahaya lampu. Hal ini menggambarkan keterbatasannya 
dalam melihat, berbicara, dan bersosialisasi dengan dunia luar.

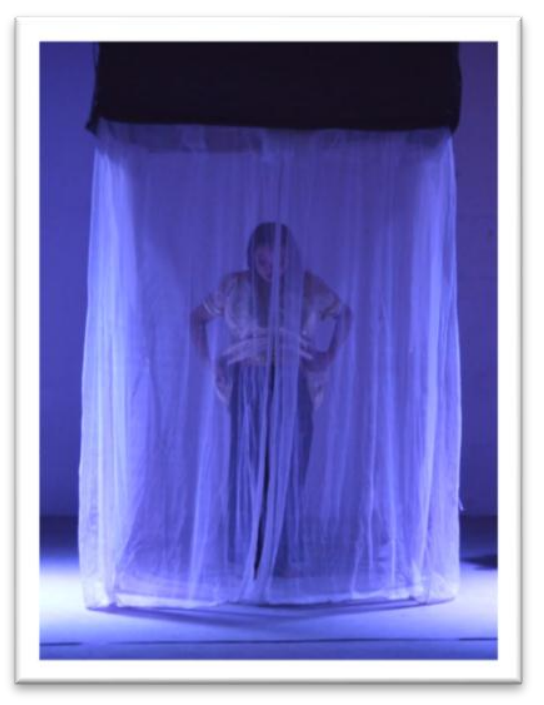

Gambar 9: Introduksi, kelambu menyiratkan keterkungkungan (Foto : Risvi, 2018)

\section{b. Adegan I}

Penari 2 masuk dengan tangan yang ditutupi kain meengekspresikan pencarian jati dirinya yang masih mengikuti tradisi dan ingin lepas dari ikatan. Penari 3 masuk dengan ekspresi kebebasan, bebas berinteraksi dengan dunia luar dan bebas mengungkapkan pandangan serta ideologinya.

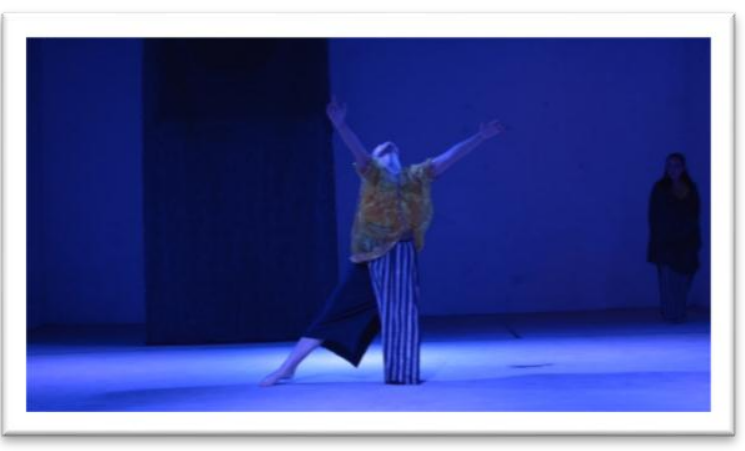

Gambar 10 : Penari 2 penggambaranketerbatasan (Foto : Risvi, 2018)

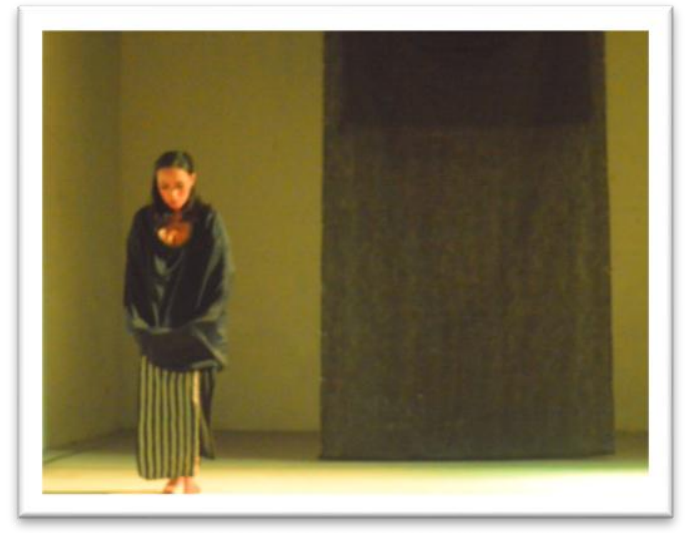

Gambar 11 : penari 3 penggambaran kebebasan (Foto : Risvi, 2018)

c. Adegan II

Terjadi konflik yang membuat kecemburuan, ketertekanan karena adanya perbedaan. Penari 2 mencoba mengikuti penari 3 untuk lepas dari tradisi dan mengikuti perkembangan zaman yang semakin maju. Terjadi pemberontakan hati yang akhirnya penari 2 melepas ikatan tradisinya dan mencoba kebebasan yang dialami. Penari 2 dan penari 3 mencoba mepengaruhi penari 1 yang masih memegang perilaku sosial dan pola pikir 
JOGED

ISSN: $1858-3989$
Waode Muriani Ekasari Virno Bolu I BAWINE: KARYA TARI YANG TERISNPIRASI PADA CITRA PEREMPUAN BUTON yang masih terbatas. Sehingga semua penari ke luar dari aturan dan mencoba mengikuti perkembangan zaman.

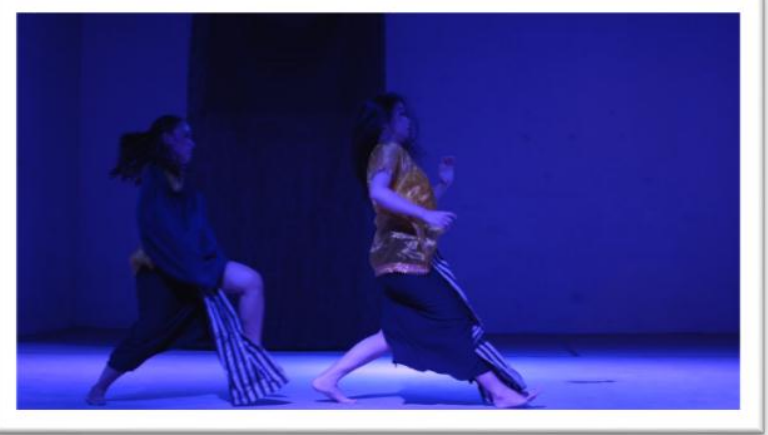

Gambar 12: Konflik yang membuat kecemburuan penari 2 , ketertekanan karena adanya perbedaan dengan penari 3

(Foto : Risvi, 2018)

\section{d. Adegan III}

Kebebasan berbicara, berinteraksi dengan semua makhluk sosial membuat keresahan tersendiri bagi penari 1 , sehingga penari 1 menatap dirinya dari luar skat dan memutuskan untuk tetap menerobos pembatas dan membuat mereka tetap teguh melindungi dirinya dalam tradisi dan mengikuti perkembangan zaman.

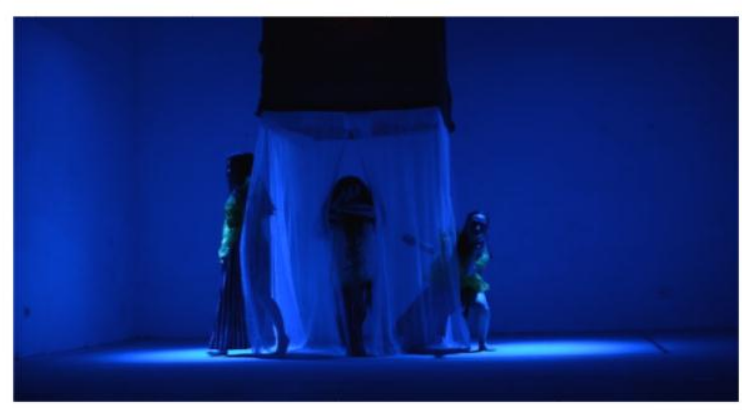

Gambar 13 : Ketiga penari menerobos pembatas sebagai simbol kebebasan (Foto : Risvi, 2018)

\section{PENUTUP}

Karya Bawine merupakan karya dengan konsep dramatik yang diharapkan mampu memberikan manfaat penting bagi penata dan orang lain. Pesan yang ingin disampaikan adalah memunculkan kesadaran baru mengenai nasib dan kondisi perempuan yang terkungkung dan mengalami perlakuan yang kurang adil, sehingga perlu direformasi.

Bagaimana seorang perempuan yang zaman dahulu menghadapi kehidupannya yang memiliki ruang lingkup yang terbatas, dan bagaimana seorang perempuan berusaha untuk bisa ke luar dari keterkungkungan tersebut. Kebebasan dalam menentukan pilihan ini bisa dilihat dalam citra perempuan dalam Khabanti yang mempertanyakan nasibnya dan ingin melakukan perubahan. Sedangkan jika dilihat dari cerita rakyat Wandiu ndiu kebebasan dalam memilih terlihat pada peran si ibu dalam menentukan pilihannya dengan meninggalkan keluarganya. Tema perempuan ini akan mengarah sebagai patokan untuk membantu dalam proses penggarapan agar pesan yang diinginkan dapat tersampaikan. 


\section{DAFTAR SUMBER ACUAN}

\section{A. Sumber Tertulis}

Fay, Brian. 2002, Filsafat Ilmu Sosial Kontemporer (Terjemahan Buku Contemporary Philosophy of Sosial Science). Yogyakarta: Penerbit Jendela

Hadi, Y. Sumandiyo, 1988, Mencipta Lewat Tari (Terjemahan Buku Creating Thourgh Dance). Yogyakarta: Institut Seni Indonesia Yogyakarta.

Hardiman, Budi F. 2015. Seni Memahami: Hermeneutik dari Schleirmacher sampai Derrida. Yogyakarta: Kanisius.

Khotimah, Khusnul. 2009. "Diskriminasi Gender Terhadap Perempuan

Dalam Sektor Pekerjaan". Jurnal Studi Gender Dan Anak, Volume 4

No 1 Jan-Jun 2009 : 158-180.

Royce, Anya Peterson. 2007. Antropologi Tari. Diterjemahkan oleh FX. Widaryanto. Bandung: Sunan Ambu Press.

Smith, Jacqueline. 1995. Komposisi Tari: Sebuah Petunjuk Praktis Bagi Guru, Terjemahan Ben Suharto, Yogyakarta : Ikalasti

Udu, Sumiman. 2006, "Citra Perempuan Dalam Khabati", dalam Disertasi pada Program Studi Pascasarjana Sastra Universitas Gajah Mada Yogyakarta.

\section{B. Discografi}

Kalegoa: Proses Pingitan Masyarakat Buton. Oleh La Ode Umuri Bolu.

Pakarena: Menunjukan Siklus Kehidupan Manusia. 